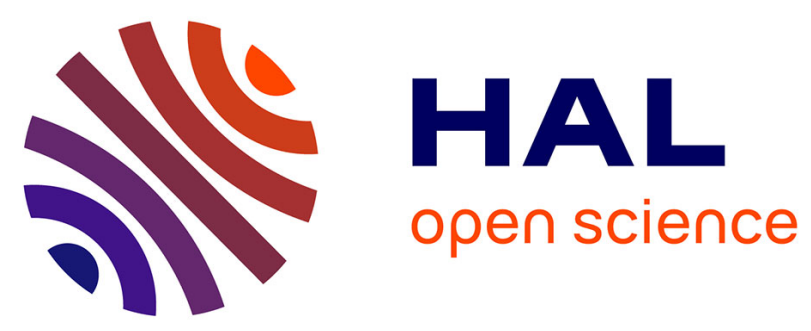

\title{
Rating curves and estimation of average water depth at the upper Negro River based on satellite altimeter data and modeled discharges
}

Juan Gabriel Leon, Stéphane Calmant, F. Seyler, Marie-Paule Bonnet, Mathilde Cauhopé, Frédéric Frappart, Naziano Filizola, Pascal Fraizy

\section{To cite this version:}

Juan Gabriel Leon, Stéphane Calmant, F. Seyler, Marie-Paule Bonnet, Mathilde Cauhopé, et al.. Rating curves and estimation of average water depth at the upper Negro River based on satellite altimeter data and modeled discharges. Journal of Hydrology, 2006, 328 (3-4), pp.481-496. 10.1016/J.JHYDROL.2005.12.006 . hal-00323534

\section{HAL Id: hal-00323534 https://hal.science/hal-00323534}

Submitted on 21 Apr 2010

HAL is a multi-disciplinary open access archive for the deposit and dissemination of scientific research documents, whether they are published or not. The documents may come from teaching and research institutions in France or abroad, or from public or private research centers.
L'archive ouverte pluridisciplinaire HAL, est destinée au dépôt et à la diffusion de documents scientifiques de niveau recherche, publiés ou non, émanant des établissements d'enseignement et de recherche français ou étrangers, des laboratoires publics ou privés. 


\section{Tables}

Table 1 Principal characteristics of Negro River

\begin{tabular}{ll}
\hline Negro Basin & \\
\hline Area & $715,000 \mathrm{~km}^{2}$ \\
Mean annual temperature & $26^{\circ} \mathrm{C}$ \\
Annual rainfall & $3000-4000 \mathrm{~mm}$ \\
Soil moisture regime & Udic to Perudic \\
Rainfall peak period & April-June \\
Discharge Ranges & $4200-50,000 \mathrm{~m}^{3} / \mathrm{s}$ \\
\hline
\end{tabular}

Soil Survey Staff $(1975,1990)$, Dubroeucq and Volkoff (1998) and Guyot (1993). 
Table 2 Main characteristics of hydrologic stations studied

\begin{tabular}{|c|c|c|c|c|c|c|c|}
\hline Station name & River & Longitude & Latitude & $\begin{array}{l}\text { Measurement } \\
\text { period }\end{array}$ & Discharge $\left(\mathrm{m}^{3} / \mathrm{s}\right)$ & $\begin{array}{l}\text { Drained } \\
\text { area }\left(\mathrm{km}^{2}\right)\end{array}$ & $\begin{array}{l}\text { Upstream } \\
\text { station }\end{array}$ \\
\hline Cucui & Negro River & -66.8597 & 1.2155 & $1980-2204$ & $400-10,500$ & 70,400 & - \\
\hline Sao Felipe & Negro River & -67.3218 & 0.3727 & $1977-2004$ & $1200-15,500$ & 119,200 & Cucui \\
\hline Curicuriari (from Sao Felipe) & Negro River & -66.8115 & -0.1921 & $1977-2004$ & $2500-24,000$ & 132,000 & Sao Felipe \\
\hline Curicuriari (from Taraqua) & Negro River & -66.8115 & -0.1921 & $1977-2004$ & $2500-24,000$ & 132,000 & Taraqua \\
\hline $\begin{array}{l}\text { Serrinha } \\
\text { Curicuriari }\end{array}$ & Negro River & -64.8108 & -0.4876 & 1977-2004 & $5000-30,000$ & 283,000 & \\
\hline Uaracu & & -69.1388 & 0.4892 & 1977-2004 & $80-6000$ & 38,700 & - \\
\hline Taraqua & Uaupes River & -68.5534 & 0.1349 & $1977-2004$ & $250-6500$ & 42,000 & Uaracu \\
\hline
\end{tabular}




\begin{tabular}{|c|c|c|c|c|c|c|c|}
\hline Station & River & Latitude/longitude & Type of data & $\begin{array}{l}\text { Dry/wet season } \\
\text { cross-section } \\
\text { width }(\mathrm{km})\end{array}$ & $\begin{array}{l}\text { Discharge } \\
\text { measured by } \\
A D C P \text { in } \\
05 / 2005 \\
\left(\mathrm{~m}^{3} / \mathrm{s}\right)\end{array}$ & $\begin{array}{l}\text { Average water } \\
\text { depth by ADCP } \\
\text { in } 05 / 2005(\mathrm{~m})\end{array}$ & $\begin{array}{l}\text { Upstream In situ } \\
\text { station distance } \\
(\mathrm{km})\end{array}$ \\
\hline T493_1 & Negro & $0.87 /-66.89$ & ENVISAT & $1.72 / 2.23$ & 7071 & 8.23 & Cucui (47) \\
\hline T89_22 & Negro & $0.91 /-67.00$ & $\mathrm{~T} / \mathrm{P}$ & $1.4 / 2.08$ & 7071 & 8.40 & Cucui $(60)$ \\
\hline T536_1 & Negro & $0.92 /-67.19$ & ENVISAT & $0.76 / 1.29$ & 7623 & 10.18 & Cucui (85) \\
\hline T536_2 & Negro & $0.72 /-67.23$ & ENVISAT & $1.02 / 1.98$ & 8582 & 11.43 & Cucui (113) \\
\hline T536_3 & Negro & $0.60 /-67.26$ & ENVISAT & $0.98 / 2.19$ & 8647 & 9.32 & Cucui (128) \\
\hline T536_4 & Negro & $0.37 /-67.31$ & ENVISAT & $1.06 / 2.19$ & 11,625 & 12.24 & Sao Felipe $(0)$ \\
\hline T89_26 & Negro & $0.09 /-67.29$ & $\mathrm{~T} / \mathrm{P}$ & $0.8 / 0.84$ & 12,524 & 11.95 & Sao Felipe (33) \\
\hline T994_1 & Negro & $-0.23 /-66.73$ & ENVISAT & $1.12 / 1.52$ & 18,590 & 12.92 & Curicuriari (10.6) \\
\hline T493_2 & Negro & $-0.33 /-66.62$ & ENVISAT & $2.16 / 2.48$ & 18,569 & 11.49 & Curicuriari (26.5) \\
\hline T450_1 & Negro & $-0.32 /-66.03$ & ENVISAT & $3.65 / 3.65$ & 20,361 & 7.58 & Curicuriari (100) \\
\hline T951_1 & Negro & $-0.31 /-65.91$ & ENVISAT & $1.81 / 2.06$ & 20,445 & 11.10 & Curicuriari (114) \\
\hline T254_22 & Negro & $-0.24 /-65.81$ & $\mathrm{~T} / \mathrm{P}$ & $2.72 / 7.70$ & 21,841 & 11.48 & Curicuriari (126) \\
\hline T908_1 & Negro & $-0.37 /-65.32$ & ENVISAT & $2.91 / 2.91$ & 22,388 & 12.44 & Curicuriari (188) \\
\hline T407_1 & Negro & $-0.41 /-65.15$ & ENVISAT & $2.44 / 2.44$ & 23,460 & 11.78 & Curicuriari (207) \\
\hline T121_1 & Uaupes & $0.43 /-68.94$ & ENVISAT & $0.8 / 1.29$ & No data & No data & Uaracu (50.3) \\
\hline T178_7 & Uaupes & $0.43 /-68.89$ & $\mathrm{~T} / \mathrm{P}$ & $0.98 / 0.98$ & No data & No data & Uaracu (57) \\
\hline T622_1 & Uaupes & $0.35 /-68.75$ & ENVISAT & $1.06 / 1.69$ & No data & No data & Uaracu (80.4) \\
\hline T579_1 & Uaupes & $0.12 /-68.16$ & ENVISAT & $1.21 / 2.64$ & 4850 & 5.48 & Taracua $(60)$ \\
\hline T78_1 & Uaupes & $0.11 /-68.09$ & ENVISAT & $1.42 / 1.42$ & 4791 & 6.13 & Taraqua (69) \\
\hline T35_1 & Uaupes & $0.11 /-67.45$ & ENVISAT & $0.89 / 1.41$ & 5190 & 8.98 & Taraqua $(160)$ \\
\hline T536_5 & Uaupes & $0.09 /-67.36$ & ENVISAT & $1.02 / 1.34$ & 5204 & 10.6 & Taraqua (168) \\
\hline
\end{tabular}


Table 4 Results of the method application at three gauged stations

\begin{tabular}{lclllllrl}
\hline Station & $a$ & $b$ & $R^{2}$ & EWD $(\mathrm{m})$ & GWD $(\mathrm{m})$ & D1 $(\mathrm{m})$ & D2 $(\mathrm{m})$ & Difference between D1 and D2 \\
\hline Cucui & 314.21 & 1.502 & 0.99 & 7.99 & 9.82 & 1.83 & 2.12 & -0.29 \\
Sao Felipe & 179.08 & 1.86 & $\mathrm{p} .97$ & 11.53 & 11.75 & 0.22 & -0.19 & 0.41 \\
Curicuriari & 33.13 & 2.495 & 0.96 & 13.6 & 11.03 & 2.57 & 0.73 & 1.84 \\
Serrinha & 105.73 & 2.308 & 0.94 & 10.83 & 11.78 & 0.95 & 0.77 & 0.19 \\
\hline
\end{tabular}

GWD, gauged water depth at in situ station for the same discharge measured by the ADCP in 05/2005; EWD, estimated water depth by the rating curve for the same discharge measured by ADCP; D1, difference between GWD and EWD; D2, difference between GWD and MWD. 
Table 5 Results of the rating-curve and water depth estimations at virtual stations

\begin{tabular}{|c|c|c|c|c|c|c|c|c|c|}
\hline Station & $a$ & $b$ & $z(m)$ & $R^{2}$ & $n$ & $\begin{array}{l}\text { Average } \\
\text { estimated } \\
\text { water depth }\end{array}$ & EWD (m) & $\begin{array}{l}\text { Difference between } \\
\text { MWD and EWD (m) }\end{array}$ & $\sigma_{\mathrm{d}}(\mathrm{m})$ \\
\hline T493_1 & 594.08 & 1.26 & 70.04 & 0.98 & 17 & 4.68 & 7.26 & 0.97 & 1.38 \\
\hline T89_22 & 339.83 & 1.25 & 67 & 0.66 & 86 & 8.85 & 8.28 & 0.12 & 1.48 \\
\hline T536_1 & 412.92 & 1.35 & 68.80 & 0.99 & 16 & 6.07 & 8.66 & 1.52 & 3.48 \\
\hline T536_2 & 105.21 & 1.79 & 65 & 0.90 & 19 & 8.25 & 11.74 & -0.3 & 3.00 \\
\hline T536_3 & 206.56 & 1.63 & 66.34 & 0.98 & 18 & 6.85 & 10.05 & -0.72 & 1.61 \\
\hline T536_4 & 179.08 & 1.86 & 65.29 & 0.97 & 18 & 8.38 & 10.95 & 1.30 & 4.1 \\
\hline T89_26 & 115.64 & 2.01 & 59.5 & 0.79 & 98 & 9.64 & 9.01 & 2.94 & 7.04 \\
\hline T994_1 & 204.92 & 1.87 & 36.51 & 0.99 & 15 & 8.12 & 11.01 & 0.72 & 5.45 \\
\hline T493_2 & 257.14 & 1.79 & 35.90 & 0.98 & 15 & 8.04 & 10.80 & -0.69 & 3.76 \\
\hline T450_1 & 383.90 & 1.76 & 31.83 & 0.99 & 15 & 7.32 & 9.54 & -1.95 & 2.57 \\
\hline T951_1 & 422.10 & 1.73 & 30.29 & 0.99 & 15 & 6.93 & 9.42 & 1.68 & 8.3 \\
\hline T254_22 & 1576 & 1.001 & 25 & 0.76 & 94 & 10.23 & 11.87 & -0.39 & 4.67 \\
\hline T908_1 & 490.52 & 1.71 & 25.29 & 0.98 & 18 & 7.21 & 8.82 & -1.16 & 2.44 \\
\hline T407_1 & 553.80 & 1.67 & 24.67 & 0.99 & 15 & 7.01 & 9.37 & -2.41 & 4.54 \\
\hline T121_1 & 529.41 & 1.35 & 89.79 & 0.97 & 14 & 3.88 & - & No MWD data & - \\
\hline T178_7 & 340.95 & 1.41 & 88.29 & 0.72 & 59 & 4.23 & - & No MWD data & - \\
\hline T622_1 & 768.88 & 1.25 & 89.79 & 0.96 & 13 & 2.33 & - & No MWD data & - \\
\hline T579_1 & 175.80 & 1.71 & 73.97 & 0.99 & 13 & 4.55 & 6.78 & -1.28 & 2.69 \\
\hline T78_1 & 410.41 & 1.36 & 74.11 & 0.97 & 14 & 4.72 & 6.092 & 0.04 & 3.26 \\
\hline T35_1 & 298.13 & 1.26 & 66.17 & 0.95 & 16 & 6.25 & 9.69 & -0.71 & 3.94 \\
\hline T536_5 & 121.58 & 1.55 & 63.92 & 0.95 & 16 & 7.71 & 11.28 & -0.68 & 3.45 \\
\hline
\end{tabular}

GWD, gauged water depth at in situ station for the same discharge measured by the ADCP in 05/2005; EWD, estimated water depth by the rating curve for the same discharge measured by ADCP; MWD, measured average water depth by ADCP under each altimetric track in 05/ $2005 ; a, b$, coefficients of the rating curve (Eq. (4)); $z$, estimated zero effective flow stage from the ellipsoid WGS84 by RMSE minimization method; $R^{2}$, correlation coefficient of the rating curve; $n$, number of points in the rating curve; $\sigma_{\mathrm{d}}$, standard deviation of the depth along the ADCP profile. 
Table 6 Manning roughness coefficient along the Negro and Uaupes Rivers

\begin{tabular}{llll}
\hline Reach & $\begin{array}{l}\text { Reach } \\
\text { number }\end{array}$ & $\begin{array}{l}n \\
\text { (dry season) }\end{array}$ & $\begin{array}{l}n \\
\text { (rain season) }\end{array}$ \\
\hline T493_1-T536_4 & 1 & 0.04 & 0.076 \\
T89_26-T994_1 & 2 & 0.093 & 0.11 \\
T493_2-T254_22 & 3 & 0.037 & 0.04 \\
T908_1-T407_1 & 4 & 0.032 & 0.032 \\
T121_1-T536_5 & 5 & 0.036 & 0.054 \\
\hline
\end{tabular}




\section{Figures}

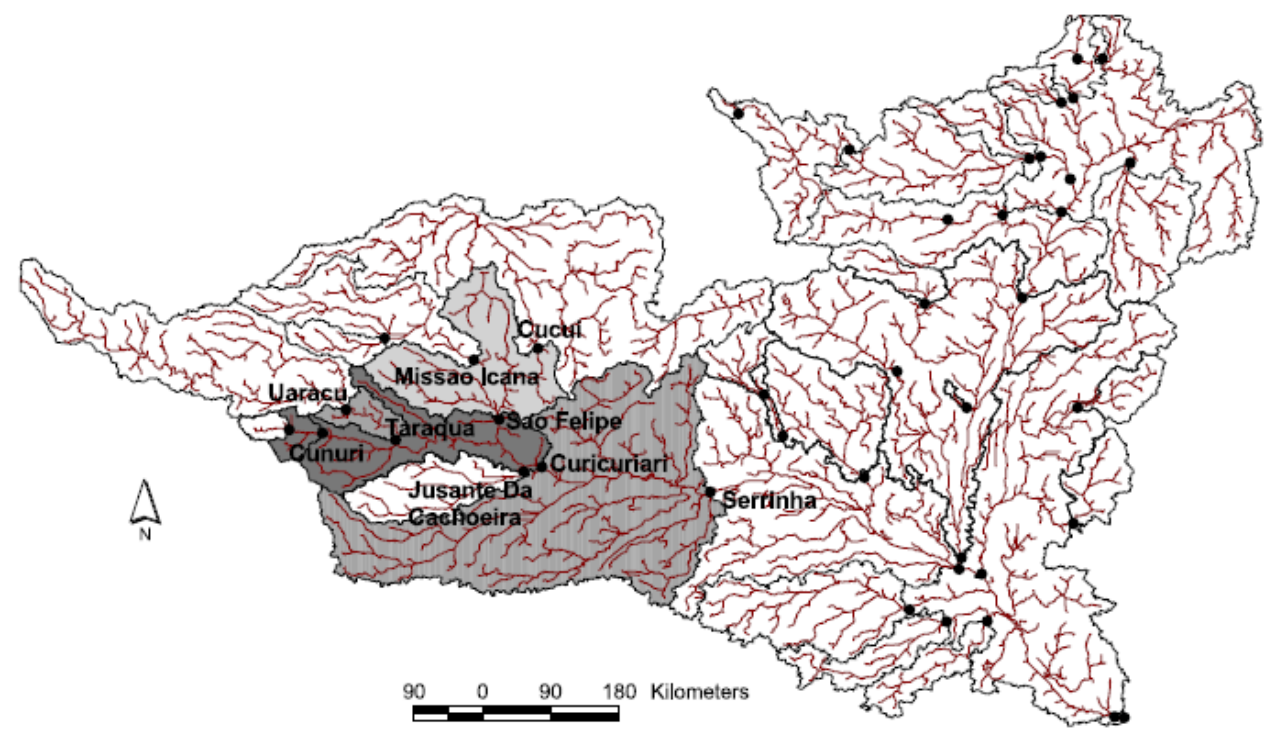

Figure 1 Negro River Basin. The Negro River and the subwatershed delineation. Black points show the position of the hydrological stations in the basin. In grey are the subwatersheds considered in this study. 


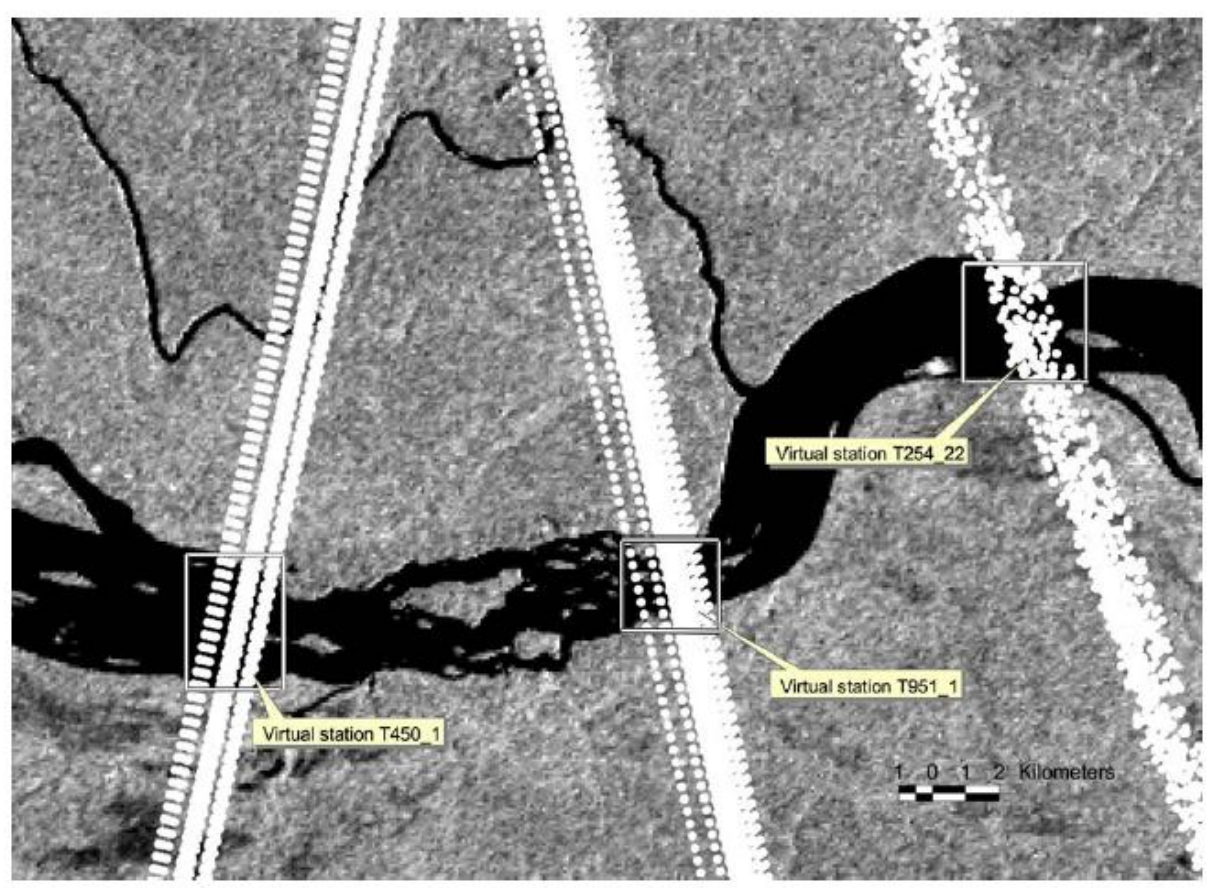

Figure 2 Virtual stations. Virtual stations selection data based on JERS image ENVISAT and T/P level measurements. The zone showed is located between Curicuriari and Serrinha in situ stations in dry season. 


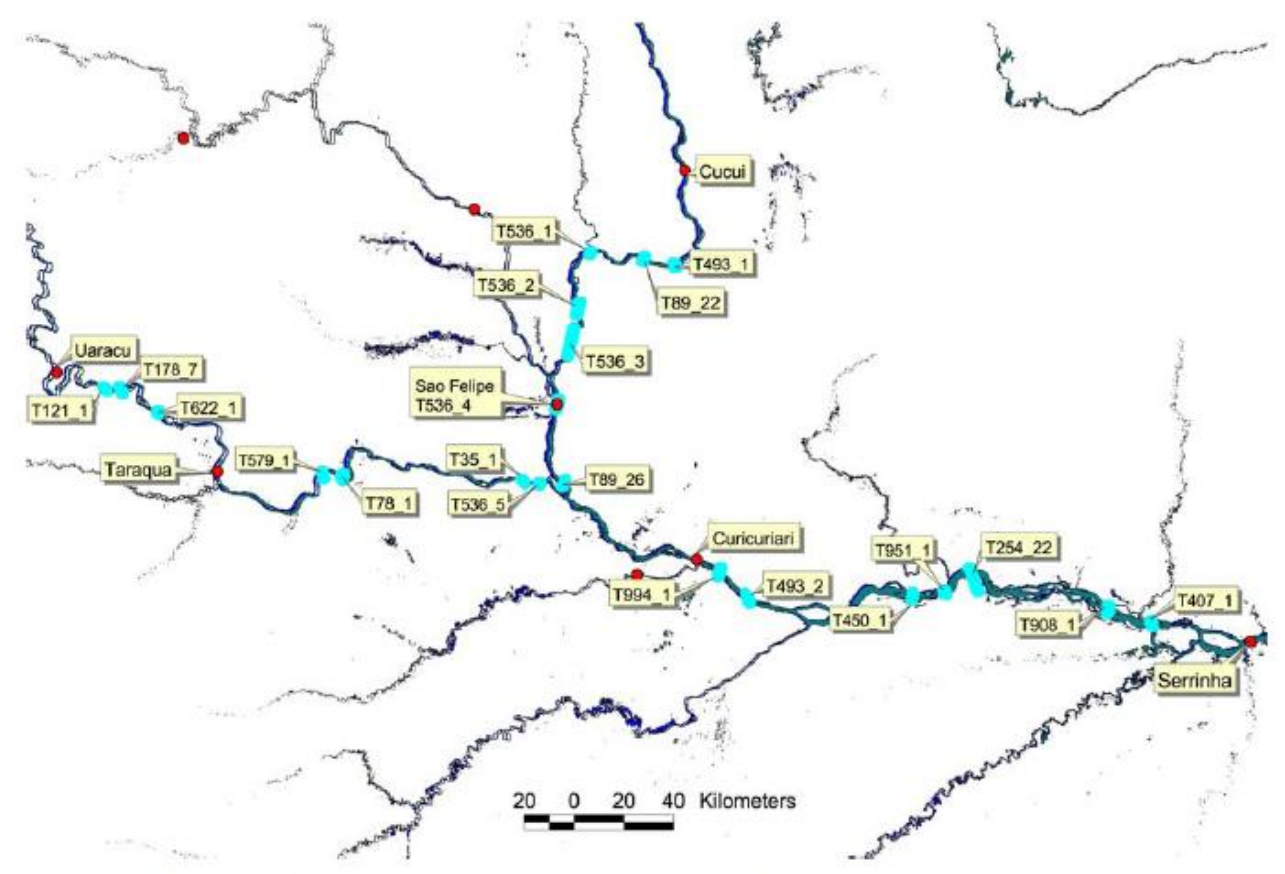

Figure 3 Virtual stations. Position of virtual stations between Cucui and Serrinha for the Negro River main stream and Uaracu et Curicuriari for the Uaupes River main stream. 

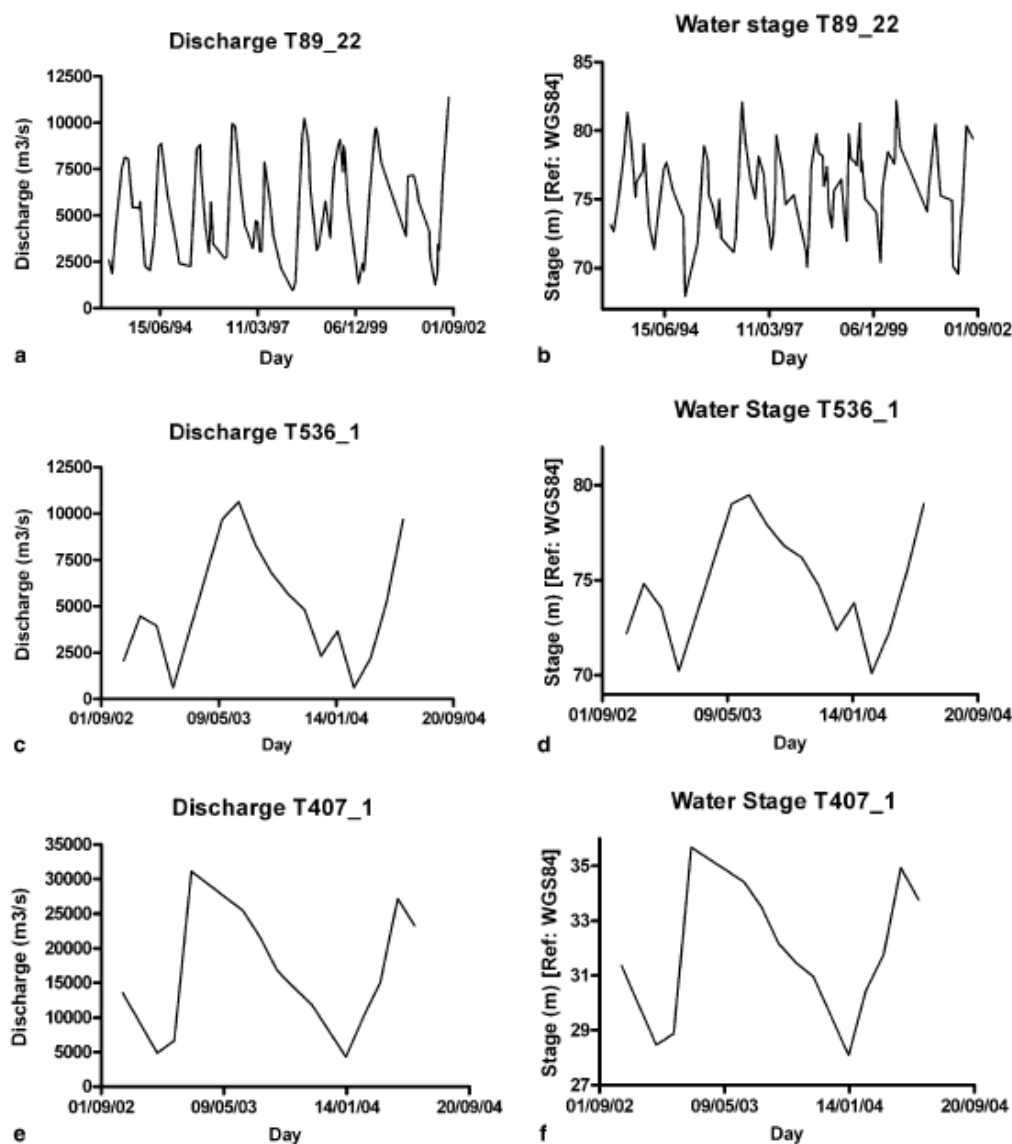

Figure 4 Discharge and water stage time series. Discharge and water stage time series of three virtual stations along the Negro River main stream. 


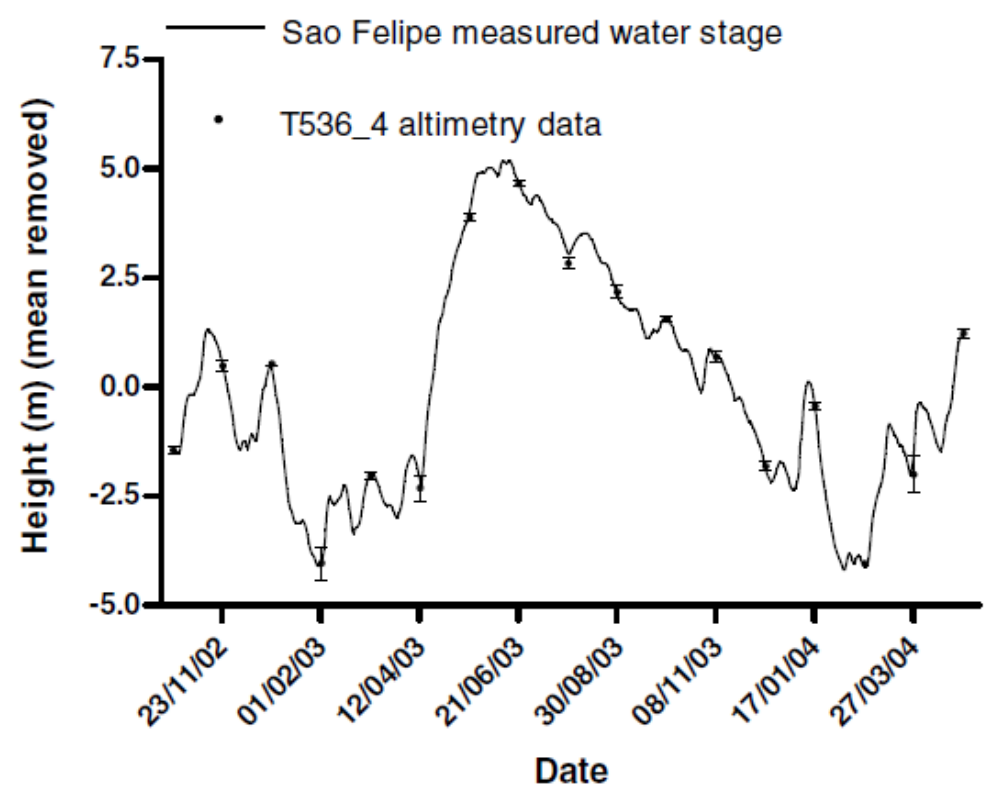

Figure 5 Time series of water stage at Sao Felipe. The thin continuous line stands for the daily in situ readings. ENVISAT heights (black dots) are reported as the median value at each pass (every 35 days) along with the standard deviation. 
T493_1

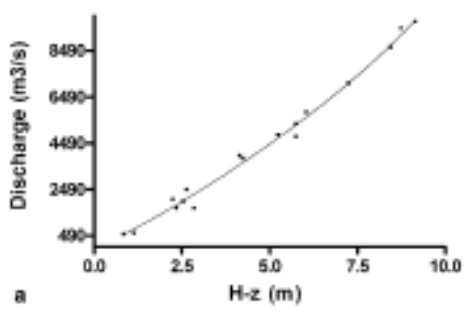

T89_26
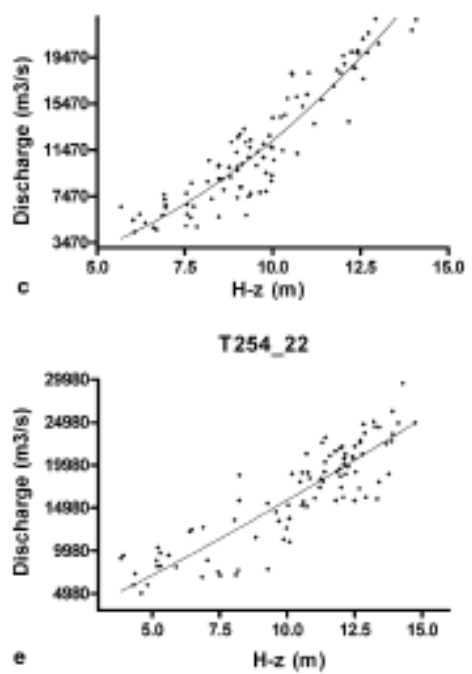

T121_1

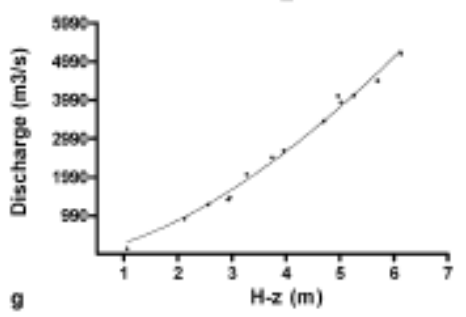

T536_3

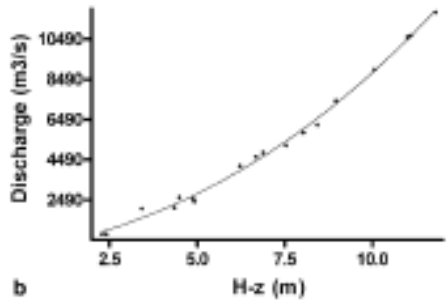

T951_1
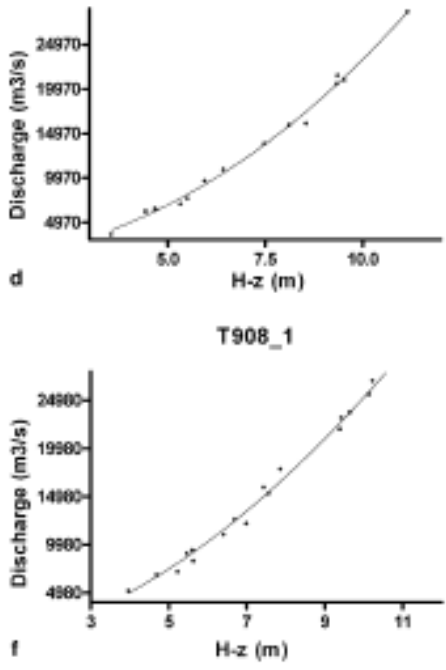

T536_5

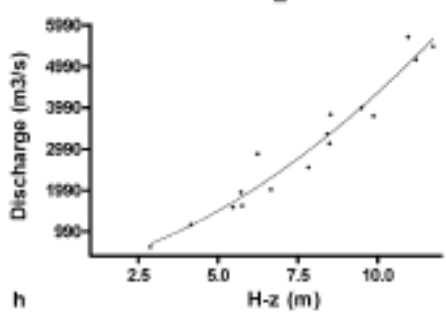

Figure 6 Estimated rating-curves. Example of estimated rating-curves for some virtual stations. 
T493_2

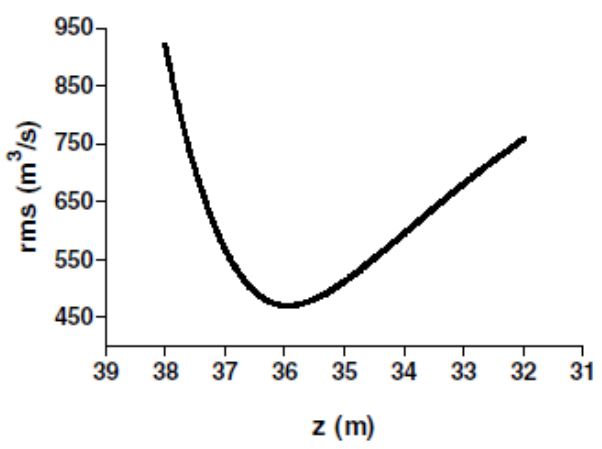

T178_7

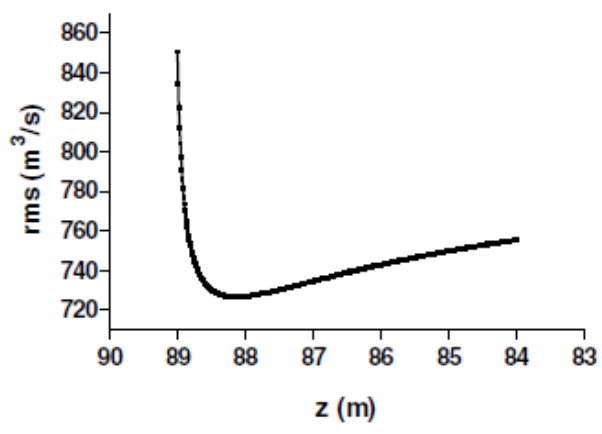

T908_1

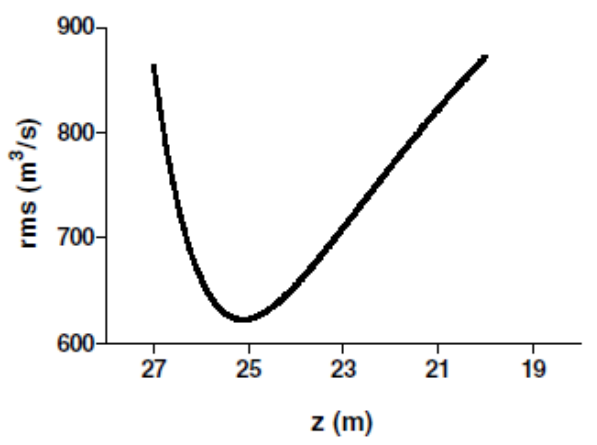

T536_5

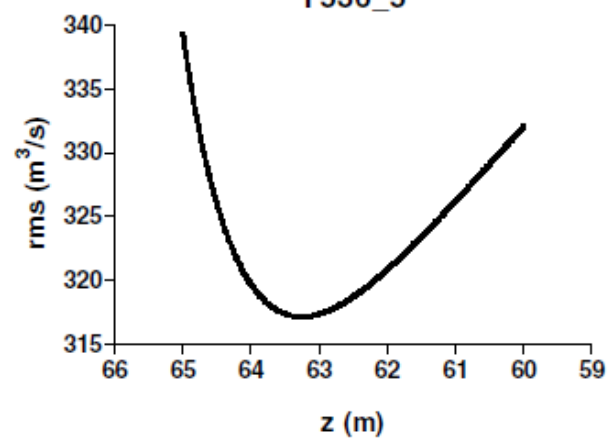

Figure 7 RMS evolution. Evolution of the RMS in discharge when the discharge-height pairs are fitted by a rating curve for successive values of the reference depth $z$. 

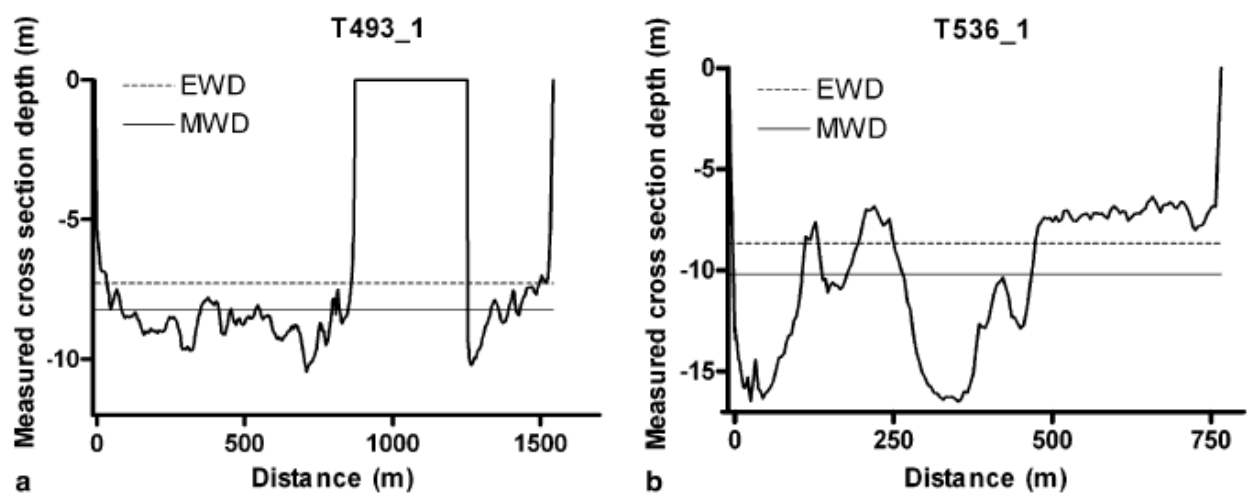

Figure 8 ADCP profiles from Cucui to Sao Felipe station (following down the Rio Negro). Measured profiles by ADCP in May 2005 for the virtual stations located between Cucui and Sao Felipe. 

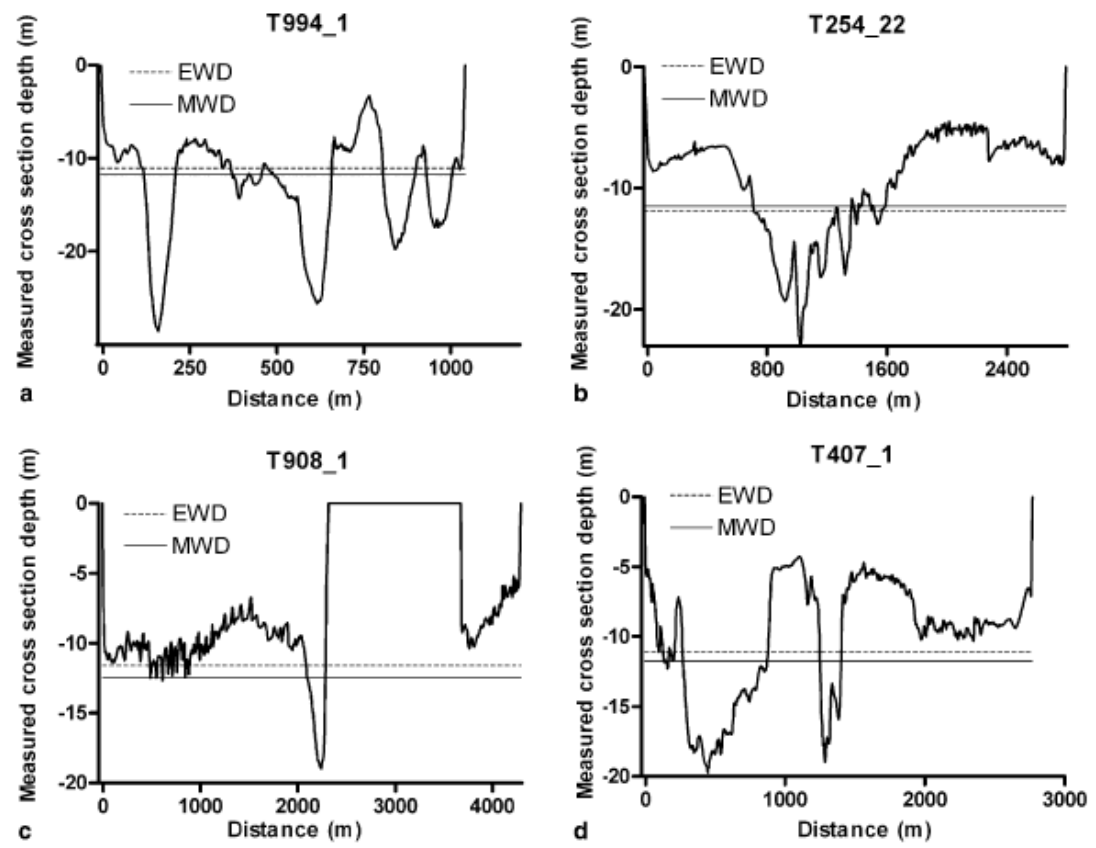

Figure 9 ADCP depth profiles at the virtual stations (following the Rio Negro, from Sao Felipe to Serrinha). Profiles collected in May 2005. 

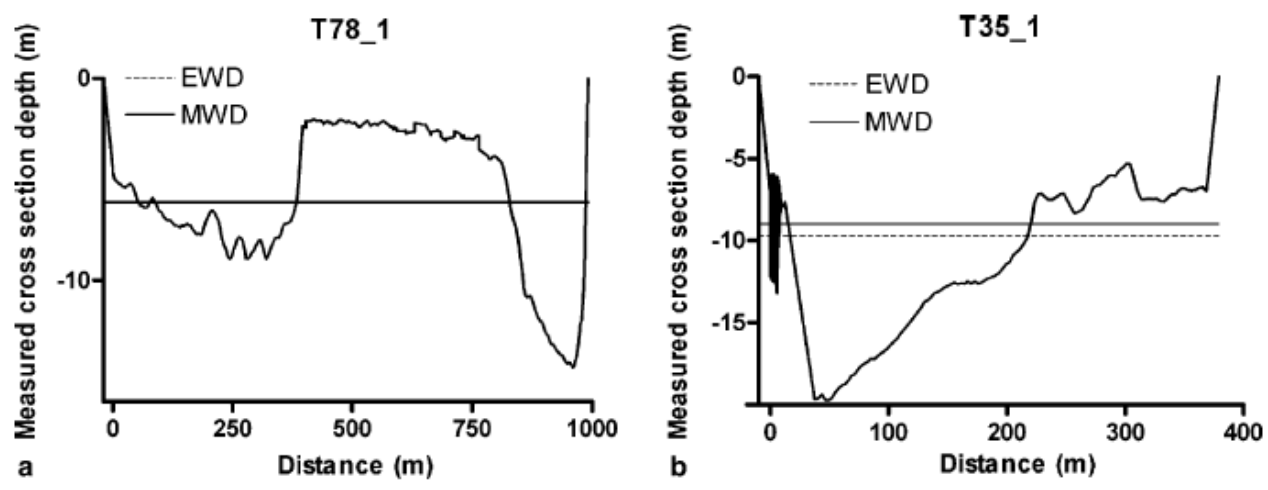

Figure 10 Uaupes River profiles. Measured profiles by ADCP in May 2005 for the virtual stations located at Uaupes River main stream. 


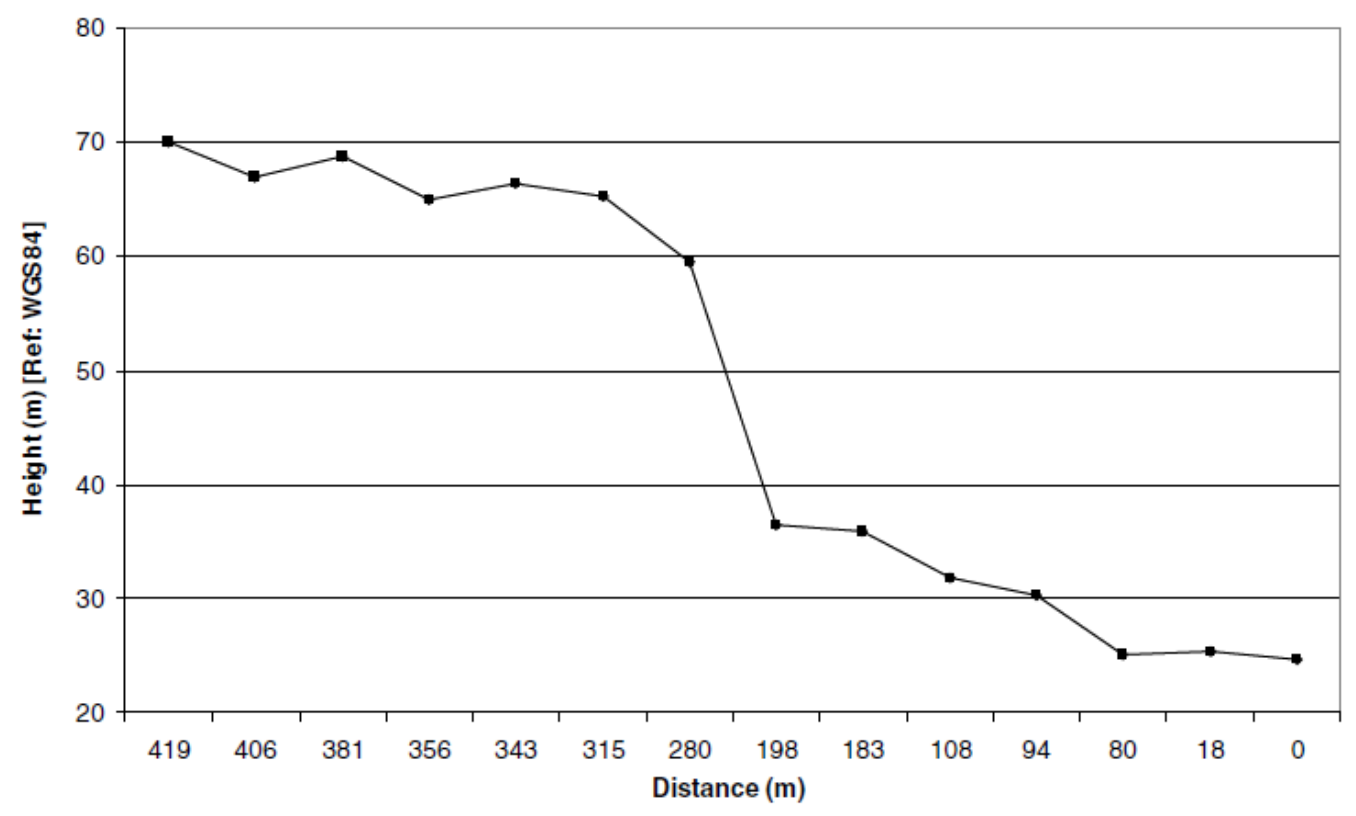

Figure 11 Negro River bed slope. Upper Negro River bottom slope profile. 


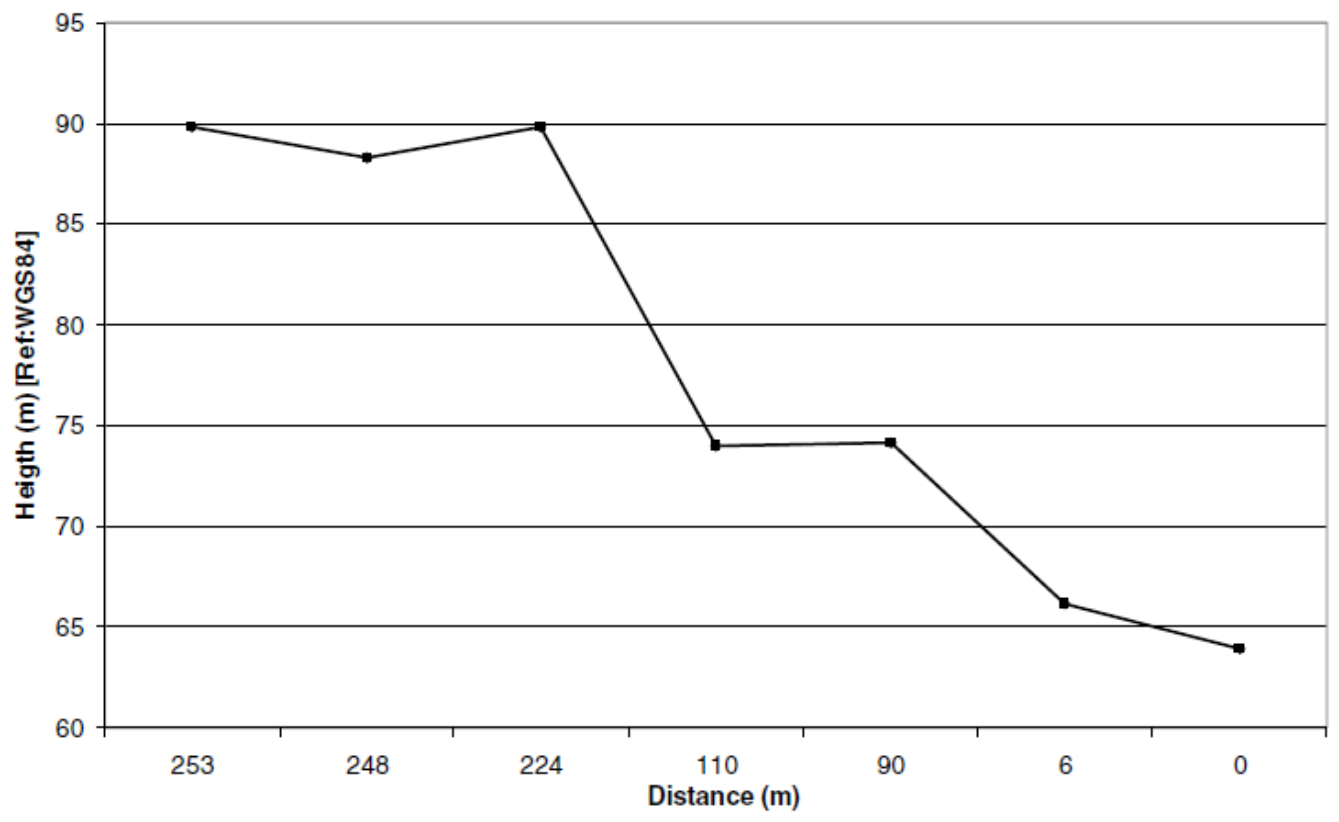

Figure 12 Uaupes River bed slope. Uaupes River bottom slope profile. 


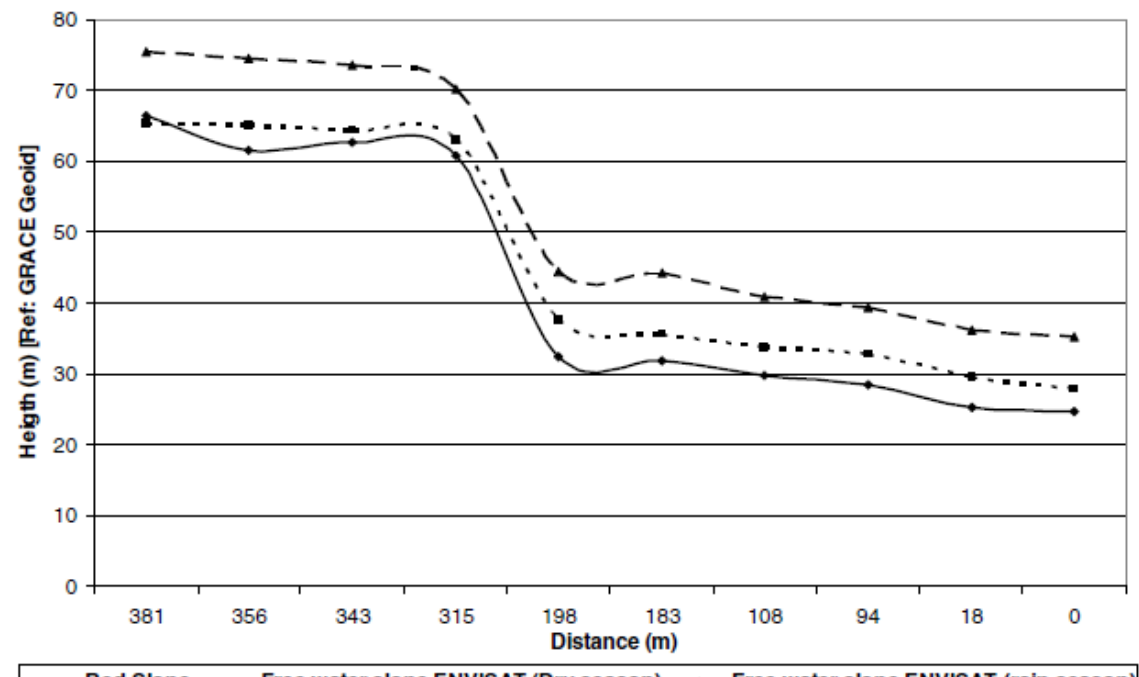

Figure 13 Negro River free water slope and bed slope. Upper Negro River free water slope calculated from ENVISAT altimetry data in dry and rainy season; and estimated bed slope. 